\title{
Economic analysis, performance, and feed efficiency in feedlot lambs
}

\section{Natália Ludmila Lins Lima', Carolina Resende de Freitas Ribeiro', Hemilly Cristina Menezes de Sá1, Izac Leopoldino Júnior ${ }^{2}$, Luigi Francis Lima Cavalcanti ${ }^{3}$, Ronan Aparecido Valadares Santana1, Iraides Ferreira Furusho-Garcia ${ }^{2}$, Idalmo Garcia Pereira ${ }^{1 *}$}

\footnotetext{
${ }^{1}$ Universidade Federal de Minas Gerais, Escola de Veterinária, Departamento de Zootecnia, Belo Horizonte, MG, Brazil.

2 Universidade Federal de Lavras, Departamento de Zootecnia, Lavras, MG, Brazil.

${ }^{3} \mathrm{CNPq}$, RHAE - Seva Engenharia, Projeto Intergado, Contagem, MG, Brazil.
}

\begin{abstract}
The objective of this study was to evaluate residual feed intake (RFI), residual intake and body weight gain (RIG) and their relationship with other traits of efficiency, performance, and economic analysis of sheep. Lambs $(\mathrm{n}=102)$ were evaluated during 56 days and a herd consisting of 500 ewes was simulated with the mean of dry matter intake (DMI) and final body weight of the lambs, the same as that of the experimental lambs. The lambs were fed hay-based diet of Tifton 85 (Cynodon spp.), corn, and soybean in the voluminous:concentrate ratio of 35:65. Residual feed intake and RIG were correlated with DMI, feed conversion ratio, and feed efficiency. Residual intake and body weight gain were positively correlated with average daily gain, relative growth rate, and Kleiber's rate. The most efficient production systems (lower RFI and higher RIG) had lower costs and higher profit margins. The net present value (NPV) and internal rate of return (IRR) were higher in systems with more efficient lambs. In systems with less efficient lambs, NPV and IRR were negative and lower, respectively. Efficient animals for RFI and RIG showed satisfactory performance and better economic results.
\end{abstract}

Key Words: cost, profit, revenue, RFI, RIG, sheep

\section{Introduction}

The termination of feedlot lambs allows the exploitation of the animal earning potential, but may become an economically unviable practice due to the cost of nutrition, which can represent approximately $70 \%$ of the cost in confinement (Barros, 2004).

To reduce the feeding costs, besides using cheaper food, it is necessary to keep an efficient herd (Lima et al., 2013). Food conversion efficiency in animal products is important for the profitability of production systems (Santana et al., 2014).

Feed efficiency can be measured by various methods, such as feed conversion ratio, relative growth rate, Kleiber's rate, residual body weight gain ( $R G)$, and residual feed intake (RFI) (Archer et al., 1999). Residual feed intake and the RG were initially proposed by Koch et al. (1963), the

Received: January 13, 2016

Accepted: July 30, 2017

*Corresponding author: idalmogp@vet.ufmg.br

http://dx.doi.org/10.1590/S1806-92902017001000005

How to cite: Lima, N. L. L.; Ribeiro, C. R. F.; Sá, H. C. M.; Leopoldino Júnior, I.; Cavalcanti, L. F. L.; Santana, R. A. V.; Furuscho-Garcia, I. F. and Pereira, I. G. 2017. Economic analysis, performance, and feed efficiency in feedlot lambs. Revista Brasileira de Zootecnia 46(10):821-829.

Copyright (C) 2017 Sociedade Brasileira de Zootecnia. This is an Open Access article distributed under the terms of the Creative Commons Attribution License (http://creativecommons.org/licenses/by/4.0/), which permits unrestricted use, distribution, and reproduction in any medium, provided the original work is properly cited. former based on intake independent growth and maturity standards and the latter based on weight gain independent intake and body weight (BW). Animals with lower RFI eat less food than that estimated to its body weight and weight gain (Leme and Gomes, 2007).

There is no way to identify animals with greater feed efficiency and higher gain through RFI because the model for the adjustment to weight gain makes it independent of the production level (Berry and Crowley, 2012). Despite low RFI, animals are efficient and those individuals with lower intake as well as lower gains may be less profitable. Thus, animals with the same RFI might have the same average daily gain in different weights and, therefore, generate different income.

This independence of performance characteristics has an impact on profit, since increasing profitability in confinement requires the identification of individuals with more efficient weight gain, as this variable is strongly correlated with profitability (Nascimento, 2011). Given the limitations on RFI, Berry and Crowley (2012) proposed a measure of feed efficiency, residual intake and BW gain (RIG), which takes into account both RFI and RG. Residual intake and BW gain identifies animals with fast growth, which, at the same time, consume less food than the average intake of the population, with no differences for BW.

The objective of this study was to evaluate two feeding efficiency measures, residual feed intake and residual 
intake and BW gain, and their correlation with the other characteristics of efficiency, performance, cost analysis, and investment in a sheep production system.

\section{Material and Methods}

The study was conducted in two stages: assessment of feeding efficiency measures on a farm in Igarapé, MG (20 $04^{\circ} 31$ South latitude, $44^{\circ} 18^{\prime} 06$ West longitude, and $786 \mathrm{~m}$ average altitude) in the second half of the years 2013 and 2014; and simulation of a property with 500 ewes using data evaluated for economic analysis and investment costs. The use of animals in the experiment was in accordance with the protocol approved by the Ethics Committee on Animal Use (CEUA), case no. 122/2012.

After 18 days of adaptation to handling and feeding, $102 \frac{1}{2}$ Dorper $\times 1 / 2$ Santa Inês male lambs of approximately 70 days old and $24.58 \pm 3.76 \mathrm{~kg}$ of initial average body weight ( \pm standard deviation) were confined for 56 days in individual pens to determine the individual feed intake. Pens had dimensions of approximately $1.0 \times 2.0 \mathrm{~m}$ and contained individual drinkers and feeding troughs. The feed was provided ad libitum in the form of total diet with roughage:concentrate ratio of 35:65 and was offered twice a day, at 8:00 and at 16:00 h. Daily feeding was done by keeping leftover percentage at $10 \%$ of the supplied food. Roughage of Tifton hay was chopped to $5 \mathrm{~mm}$. The diet was balanced so that the lambs had daily gain of $300 \mathrm{~g}$ according to NRC (2007) and contained $67.9 \%$ total digestible nutrients (TDN) and $20.5 \%$ crude protein (CP). The chemical analysis of the samples of the offered feed and leftover followed the methodology proposed by the National Institute of Science and Technology (NIST) (Detmann et al., 2012).

Along with weighting every 14 days, measurements were made of Longissimus lumborum area (LLA) and backfat thickness (BT) through ultrasound between the 12th and 13th ribs. Daily earnings (angular coefficients), LLA, and BT were also evaluated, taking time into consideration. To obtain average daily weight gain (ADG), linear regression of each animal and body weight were calculated, taking time into consideration. The first postfitting weighing was called initial body weight (BWi) and the last, after 56 days of experiment, final body weight (BWf). The observed dry matter intake (DMI) was obtained by subtracting the average amount of feed provided by the daily amount of leftover, both adjusted to dry matter (DM).

Dry matter intake (DMIe) and average daily gain (ADGe) was estimated within each group, regression of DMIe based on metabolic body weight $\left(\mathrm{BW}^{0.75}\right)$, and $\mathrm{ADG}$ of each animal during the period by the following equations, 1 and 2 , respectively:

$$
\begin{aligned}
& y_{D M I e_{i}}=\beta_{0}+\beta_{1} A D G_{i}+\beta_{2} B W_{i}^{0.75}+e_{(R F I) i}, \\
& y_{A D G e_{i}}=\beta_{0}+\beta_{1} D M I_{i}+\beta_{2} B W_{i}^{0.75}+e_{(R W G)_{i}},
\end{aligned}
$$

in which $y_{\text {DMIe }_{i}}$ is the estimated dry matter intake for the $i$-th animal; $y_{A D G e_{i}}$ is the estimated average daily gain for $i$-th animal; $\beta_{0}$ represented the intercept; $\beta_{1}$ is the linear regression coefficient of average daily gain (ADG) and dry matter intake (DMI), respectively (equations 1 and 2); $\beta_{2}$ is the regression coefficient of the metabolic body weight $\left(\mathrm{BW}^{0.75}\right)$; and $e_{i}$ is the random residual of equations 1 and 2 associated to RFI and RWG, respectively.

For comparative purposes, two classes of animals were set up based on RFI and RIG, higher ( $>$ average + 0.5 standard deviation (SD)) and lower (<average -0.5 SD). Feed conversion (FC), relative growth rate (Fitzhugh and Taylor, 1971), Kleiber's rate (Kleiber, 1947), RFI, RWG, and the RIG are contained in a brief description and calculation formula presented in Table 1 .

In Stage 2, based on the data obtained in the experiment, a projection was made for a 500-ewe module, considering the rural property where the experimental lambs originated. The number of animals kept in the herd was preset and was therefore considered a stabilized herd and the animals regarded as surplus. The animal-performance indexes were those of the herd of the property of origin and/or those considered in the literature: $85 \%$ fertility, prolificity of 1.3 lambs per ewe, $2 \%$ mortality of adult animals, $6 \%$ pup mortality, discarding $20 \%$ of the sheep, eight-month calving intervals, and $2 \%$ sheep breeding. The female sheep were divided into the category of calving (over 90 days) and pregnant (over 150 days).

Costs with pasture included $\mathrm{R} \$ 1,132.00 / \mathrm{ha}$ (ha $=10,000$ $\mathrm{m}^{2}$ ) deployment and $\mathrm{R} \$ 222.00 / \mathrm{ha}$ annual maintenance; corn silage showed a cost of $\mathrm{R} \$ 248.00 / \mathrm{t} \mathrm{DM}$; values were obtained from ANUALPEC (2014). The type of pasture employed was Brachiaria brizantha, with annual production of $10.5 \mathrm{t} \mathrm{DM} / \mathrm{ha}$ (Oliveira et al., 2003). The cost of the concentrate in confinement was $\mathrm{R} \$ 0.67 / \mathrm{kg}$ of the total diet and Tifton hay, $\mathrm{R} \$ 0.42 / \mathrm{kg}$ of diet. The total area was 79 ha and the pasture area was 59 ha. The total legal reserve and permanent preservation area was $25 \%$ and the rest of the area was improvements. The construction costs were calculated according to Brasil (2014) and installation of fences according to ANUALPEC (2014). The method for calculating the depreciation was obtained by the formula: (initial value of the property $-30 \%$ of the initial value, called residual value)/lifespan and the lifespan 
recommended by Della Giustina and Lanzer (1995). The cost of medication and vaccination was estimated based on the property where the lambs originated, as well as the cost of electricity and fuel. The cost of technical assistance was $\mathrm{R} \$ 400.00$ per visit, totaling six annual visits. The labor was divided into temporary - i.e., 30 days a year, with cost of R\$70.00 each) - and permanent - i.e., an employee who received a minimum wage $+40 \%$ social charges (R $\$ 1,103.20 /$ month), social charges according to System FAEP (2005).

To establish the opportunity cost, the value of the land, herd, improvements, pasture, and working capital was considered. The land compensation rate was $3 \%$ per year of the actual average selling price (CONAB, 2010). The value of land, according to FAEMG (2012), was R $\$ 5,000.00 /$ ha formed pasture. We decided to use $\mathrm{R} \$ 4,000.00 /$ ha because the cost of pasture establishment was calculated separately, as previously stated. Concerning the improvements, herd, machinery, equipment and pasture, and yearly interest were calculated for each asset individually by the following the formula: average value of each asset multiplied by the interest rate of $6 \%$ per year (Canziani, 2005; CONAB, 2010). The interest rate on working capital (variable cost + fuel - taxes) was $6 \%$ and only half the value was considered because the disbursement took place throughout the year. The ICMS (Government tax) was calculated at $4.4 \%$ rate on revenues from the total sales and the Rural Land Tax of $0.07 \%$ on the value of the land (Pitelli and Bacha, 2006). General maintenance and expenses accounted for $1 \%$ of the variable cost, except for technical assistance and taxes. All prices used in the calculations were carried out in 2013 and 2014 and, when not available in the literature, were obtained through budgets and market research. The sales prices were based on those used in the Midwest region of Minas Gerais, $\mathrm{R} \$ 6.80$ per kilogram of live lamb ending with $40 \mathrm{~kg}$ and $\mathrm{R} \$ 4.50$ per kilo of disposal animal with $60 \mathrm{~kg}$.

With all the items comprising the cost of producing sheep, a spreadsheet was elaborated with the following breakdown: variable operating cost (VOC), fixed operating cost (FOC), total operational cost (TOC), opportunity cost (OC), and total cost (TC). Fixed operating cos was considered that which did not vary according to the level of production and VOC, the opposite. Total operational cost was the sum of VOC + FOC and the total cost was TOC plus the opportunity cost (Barbosa and Souza, 2007; Barbosa et al., 2010; Santana et al, 2013). The revenues of activity were composed of the sales of lambs (R $\$ 450.00)$, lamb sales intended for slaughter, and sale of disposal animals (ewe). The calculation of costs and revenues allowed to carry out an economic analysis. Gross profit was obtained by subtracting the VOC revenue, while net margin (operating profit) was obtained by subtracting the revenue from TOC. The profit was the subtraction of revenue from TC. The profitability was the net margin divided by revenue and return net margin divided by the total investment (Barbosa and Souza, 2007; Barbosa et al., 2010; Santana et al., 2013). Cash flow was accomplished by deducting the expenditures from the revenue (TOC - depreciation), which resulted in the balance that is fixed every year by the interest rate of $6 \%$ per annum (Barbosa and Souza, 2007). In year 0 , the total value of the investment was obtained and from year 1 to 15 , the amount of expenses and income was obtained considering the renewal of assets or animals that were depreciated during this period. Regarding the land, its recovery or not was considered, being its appreciation at a rate of $10 \%$ per annum (MAPA, 2008). The cash flow

Table 1 - Definition of the indicator traits of feed efficiency

\begin{tabular}{|c|c|c|}
\hline Trait & Formula $^{1}$ & Definition \\
\hline Feed conversion ratio (FCR; kg DM/kg) & $\frac{D M I}{A D G}$ & $\begin{array}{l}\text { Amount of feed consumed divided by the weight gain. Lower values } \\
\text { are favorable. }\end{array}$ \\
\hline Relative growth rate (RGR; kg BW/day) & $100 \times\left[\frac{(\log B W f-\log B W i)}{(\text { Days in test })}\right]$ & $\begin{array}{l}\text { Growth potential in relation to degree of maturity. Higher values are } \\
\text { favorable. }\end{array}$ \\
\hline Kleiber's ratio (KR; g gain/kg BW ${ }^{0.75}$ ) & $100 \times\left[\frac{A D G}{B W^{0.75}}\right]$ & $\begin{array}{l}\text { ADG, in grams, proportional to each kilogram of metabolic weight. } \\
\text { Higher values are favorable. }\end{array}$ \\
\hline Residual feed intake (RFI; kg DM/day) & $D M I-D M I e$ & $\begin{array}{l}\text { Difference between observed and estimated DMI based on ADG and } \\
\mathrm{BW}^{0.75} \text {. Lower values are favorable. }\end{array}$ \\
\hline Residual weight gain (RWG; kg gain/day) & $A D G-A D G e$ & $\begin{array}{l}\text { Difference between observed and estimated ADG based on DMI and } \\
\mathrm{BW}^{0.75} \text {. Higher values are favorable. }\end{array}$ \\
\hline Residual intake and BW gain (RIG) & $R W G+[(-1) \times R F I]$ & $\begin{array}{l}\text { Simple index including RFI and RWG whose variance is adjusted at } 1 . \\
\text { Higher values are favorable. }\end{array}$ \\
\hline
\end{tabular}

Adapted from Grion et al. (2014).

DM - dry matter; ADG - average daily weight gain; DMI - dry matter intake; BW - body weight; BWf - final BW; BWi - initial BW; BW ${ }^{0.75}$ - metabolic BW; DMIe - estimated DMI; ADGe - estimated ADG. 
over the following fifteen years was considered to calculate the net present value (NPV) and the internal rate of return (IRR) of each treatment through spreadsheets using Excel (Microsoft Corporation, 2010) according to Guimarães and Canziani (2004).

The results obtained in the experiment (Stage 1) were analyzed using R (R Development Core Team, 2015). A randomized block design was used, in which the blocks were four groups for slaughter, two in 2013 and two in 2014 (27, 20, 25, and 30 animals each), according to the following statistical model:

$$
y_{i j k}=\mu+\alpha_{i}+\beta_{j}+e_{i j k},
$$

in which $y$ (and its subscripts) represents the observed value for each variable; $\mu$ is the overall constant present in all observations; $\alpha_{i}$ is the fixed effect of $i$-th class of RFI or RIG; $\beta_{j}$ is the fixed effect of $j$-th group of slaughter; and $e_{i j k}$ is the random residual error, associated with each observation $\left(y_{i j k}\right)$, supposed normally distributed and independent with zero mean and variance $\sigma^{2}$.

Based on this statistical model, all the dependent variables had their residual estimates tested for normality by the Shapiro-Wilk test $(\mathrm{P}>0.05)$. For the FC and feed efficiency (FE) variables, since they are resultant from the ratio between the average daily gain and the dry matter intake, they no longer present normal distribution (Detmann et al., 2005).

Therefore, the FC and FE data that did not present normal distribution were transformed by using the natural logarithm or by means of Box-Cox transformation analysis through the TRANSREG procedure of SAS (Statistical Analysis System, version 9.1.0). Transformed data were used in the statistical analysis to generate the presented P-values. However, the corresponding means and standard errors were presented in the original scale to ease the interpretation of results.

Data from feed efficiency measures (RFI and RIG) were subjected to analysis of variance and Pearson's correlations were also performed. The differences of data were evaluated by the $\mathrm{F}$ test at $5 \%$ probability. The economic results (Stage 2) were obtained by calculations in spreadsheets developed in Excel (Microsoft Corporation, 2010), compared by descriptive statistics.

\section{Results}

The average DMI of the lambs was $1.350 \mathrm{~kg}$, ranging from 0.770 to $1.735 \mathrm{~kg}$ (Table 2). The ADG was similar to that established by the NRC (2007); thus, the diet provided ADG close to $300 \mathrm{~g}$.

The animal with lower RFI $(-0.15 \mathrm{~kg} /$ day $)$ ingested less feed than the animal with the highest RFI value $(0.22 \mathrm{~kg} /$ day $)$, which represents a difference of $0.38 \mathrm{~kg} /$ day between them. For both RFI and RIG, no differences $(\mathrm{P}>0.05)$ were observed in initial body weight, final body weight, mid-test body weight, and metabolic body weight, with averages of $24.65,40.86,32.80$, and $13.69 \mathrm{~kg}$, respectively (Table 2). These efficiency measures (RFI and RIG) showed no correlation with body weight measurements. These efficiency measures (RFI and RIG) showed no correlation with body weight measurements (Table 3 ).

Animals with higher RIG did not differ from those with lower RIG in regard to DMI ( $\mathrm{P}>0.05)$, with $1.353 \mathrm{~kg}$

Table 2 - Mean, standard deviation (SD), minimum, maximum, and phenotypic correlation of performance measures and feed efficiency with residual feed intake (RFI) and residual intake and body weight gain (RIG) in lambs

\begin{tabular}{|c|c|c|c|c|c|c|}
\hline Item & Mean & $\mathrm{SD}$ & Minimum & Maximum & RFI & RIG \\
\hline Initial body weight (kg) & 24.65 & 3.71 & 15.92 & 33.74 & -0.001 & -0.113 \\
\hline Final body weight (kg) & 40.86 & 4.92 & 28.74 & 51.88 & 0.007 & 0.090 \\
\hline Mid-test body weight (kg) & 32.80 & 4.04 & 23.18 & 41.42 & -0.001 & 0.010 \\
\hline Metabolic body weight (kg) & 13.69 & 1.27 & 10.56 & 16.33 & 0.0001 & 0.009 \\
\hline Dry matter intake (kg/day) & 1.35 & 0.19 & 0.77 & 1.73 & $0.413 *$ & $-0.216^{*}$ \\
\hline Average daily gain (kg/day) & 0.29 & 0.05 & 0.15 & 0.38 & -0.001 & $0.328 * *$ \\
\hline Feed conversion ratio $(\mathrm{F}: \mathrm{G})$ & 4.70 & 0.64 & 3.53 & 6.85 & $0.443 * *$ & $-0.685 * *$ \\
\hline Feed efficiency (G:F) & 0.21 & 0.02 & 0.14 & 0.28 & $-0.462 * *$ & $0.699 * *$ \\
\hline Relative growth rate & 0.39 & 0.07 & 0.21 & 0.57 & -0.006 & $0.332 * *$ \\
\hline Kleiber's ratio & 0.02 & 0.00 & 0.01 & 0.02 & -0.010 & $0.355^{* *}$ \\
\hline Residual feed intake (kg/day) & 0.00 & 0.08 & -0.15 & 0.22 & - & $-0.920 * *$ \\
\hline Residual body weight gain (kg/day) & -0.00 & 0.03 & -0.06 & 0.09 & $-0.695 * *$ & $0.920 * *$ \\
\hline Residual intake and body weight gain & 0.00 & 1.84 & -4.67 & 4.98 & $-0.920 * *$ & - \\
\hline Longissimus thoracis area (LTA) $\left(\mathrm{cm}^{2}\right)$ & 9.89 & 1.30 & 6.63 & 13.52 & -0.101 & 0.122 \\
\hline Increase rate LTA $\left(\mathrm{cm}^{2} /\right.$ day $)$ & 0.08 & 0.02 & 0.01 & 0.15 & 0.052 & 0.054 \\
\hline Backfat thickness (BT) (mm) & 3.30 & 0.43 & 2.50 & 4.60 & -0.084 & 0.040 \\
\hline Increase rate $\mathrm{BT}$ (mm/day) & 0.03 & 0.01 & 0.01 & 0.07 & -0.040 & 0.011 \\
\hline
\end{tabular}

$*(\mathrm{P}<0.05)$.

$* *(\mathrm{P}<0.01)$. 
average. This result may be due to the poor correlation $(-0.216)$ between the measures RIG and DMI, whilst the correlation between RFI and DMI was moderate $(r=0.413$; Table 2). Animals with lower RFI consumed, on average, $0.17 \mathrm{~kg} /$ day feed, $12 \%$ less than the animals with higher RFI $(\mathrm{P}<0.01)$.

Average daily weight gain was not influenced by RFI $(\mathrm{P}>0.05)$ and there was no significant correlation between them (Tables 2 and 3). Thus, efficient animals may have higher or lower ADG, which was expected (Figure 1). Average daily weight gain was different between classes of RIG $(\mathrm{P}<0.01)$ and had moderate positive correlation (0.328), being observed the highest gain in higher RIG ( 0.265 vs. $0.307 \mathrm{~kg}$ /day).

Feed efficiency measures and FCR were highly correlated with RIG ( 0.699 and -0.685 , respectively) and moderately correlated with RFI $(-0.462$ and 0.443 , respectively) (Table 2). Feed efficiency and FC differed $(\mathrm{P}<0.01)$ between classes of RFI and RIG, in which the lowest value of FC and the highest of FE were observed in higher RIG lambs (4.48 and 0.23, respectively).

For relative growth rate (RGR) and Kleiber's rate (KR), there were no differences $(\mathrm{P}>0.05)$ between the classes of RFI of the lambs. Among the RIG classes, there were some differences in the values of RGR and $K R(P<0.01)$, with higher values observed in animals with higher RIG (0.41 and 0.02 , respectively).
Relative feed intake and RIG showed no correlation $(\mathrm{P}>0.05)$ with any of the carcass characteristics evaluated by ultrasound and, likewise, there was no difference $(\mathrm{P}>0.05)$ between classes of feed efficiency by RFI and RIG for the

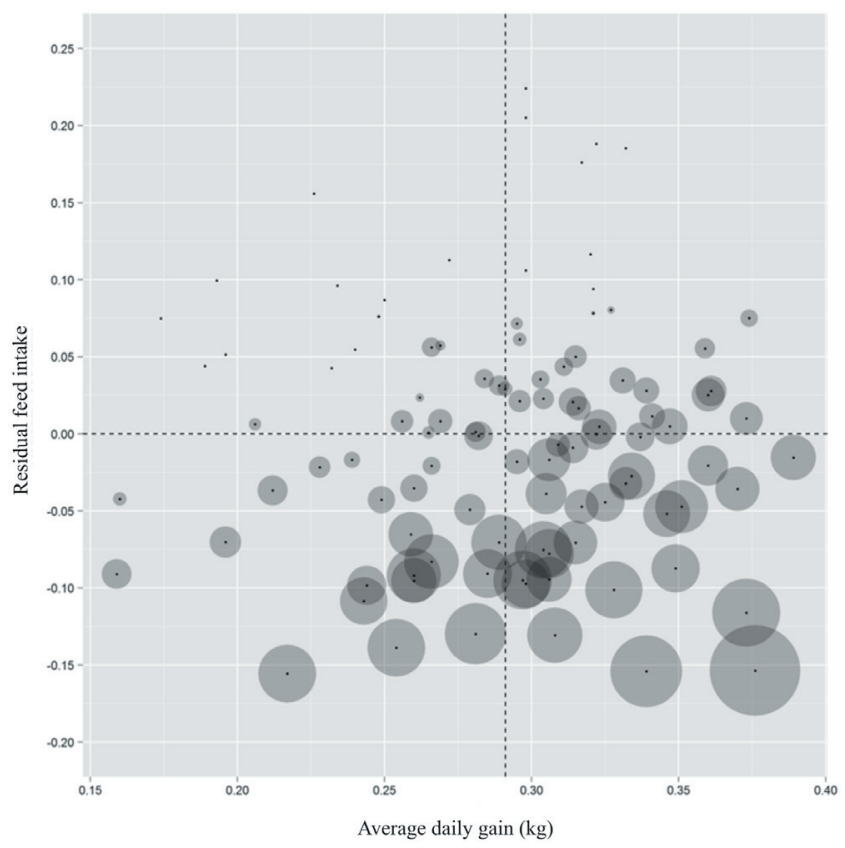

Diameter of halos corresponds to the residual intake and body weight gain.

Figure 1- Average daily gain according to the residual feed intake of the lambs.

Table 3 - Performance and feed efficiency traits for lambs ranked high and low for residual feed intake and residual intake and body weight gain

\begin{tabular}{|c|c|c|c|c|c|c|c|}
\hline \multirow{2}{*}{ Item } & \multicolumn{3}{|c|}{ Residual feed intake } & \multicolumn{3}{|c|}{ Residual intake and body weight gain } & \multirow{2}{*}{ SE } \\
\hline & Low $(n=32)$ & High $(n=29)$ & P-value & Low $(n=26)$ & $\operatorname{High}(\mathrm{n}=32)$ & P-value & \\
\hline Initial body weight (kg) & 24.78 & 24.86 & 0.759 & 25.36 & 24.54 & 0.335 & 0.370 \\
\hline Final body weight (kg) & 40.62 & 40.30 & 0.504 & 40.15 & 41.70 & 0.355 & 0.490 \\
\hline Mid-test body weight (kg) & 32.78 & 32.67 & 0.962 & 32.79 & 33.15 & 0.734 & 0.402 \\
\hline Metabolic body weight (kg) & 13.67 & 13.65 & 0.966 & 13.68 & 13.79 & 0.733 & 0.127 \\
\hline Dry matter intake (kg/day) & $1.24 \mathrm{~b}$ & $1.41 \mathrm{a}$ & $<0.01$ & $1.39 \mathrm{a}$ & $1.31 \mathrm{~b}$ & 0.180 & 0.020 \\
\hline Average daily gain (kg/day) & 0.28 & 0.27 & 0.086 & $0.26 \mathrm{~b}$ & $0.30 \mathrm{a}$ & $<0.01$ & 0.005 \\
\hline Feed conversion ratio $(\mathrm{F}: \mathrm{G})$ & $4.43 b$ & $5.15 \mathrm{a}$ & & $5.32 \mathrm{a}$ & $4.28 \mathrm{~b}$ & & 0.064 \\
\hline Feed conversion ratio $(\mathrm{F}: \mathrm{G})^{1}$ & $0.77 b$ & $0.80 \mathrm{a}$ & $<0.01$ & $0.81 \mathrm{a}$ & $0.76 b$ & $<0.01$ & 0.003 \\
\hline Feed efficiency (G:F) & $0.22 \mathrm{a}$ & $0.19 b$ & & $0.19 b$ & $0.23 \mathrm{a}$ & & 0.003 \\
\hline Feed efficiency $(G: F)^{1}$ & $-0.77 \mathrm{a}$ & $-0.80 \mathrm{~b}$ & $<0.01$ & $-0.81 b$ & $-0.76 \mathrm{a}$ & $<0.01$ & 0.002 \\
\hline Relative growth rate & 0.39 & 0.38 & 0.155 & $0.36 \mathrm{~b}$ & $0.41 \mathrm{a}$ & $<0.01$ & 0.007 \\
\hline Kleiber's ratio & 0.02 & 0.02 & 0.135 & $0.01 \mathrm{~b}$ & $0.02 \mathrm{a}$ & $<0.01$ & 0.0003 \\
\hline Residual feed intake (kg/day) & $-0.08 b$ & $0.09 \mathrm{a}$ & $<0.01$ & $0.09 \mathrm{a}$ & $-0.08 \mathrm{~b}$ & $<0.01$ & 0.008 \\
\hline Residual body weight gain (kg/day) & $0.02 \mathrm{a}$ & $-0.02 b$ & $<0.01$ & $-0.03 b$ & $0.02 \mathrm{a}$ & $<0.01$ & 0.003 \\
\hline Residual intake and body weight gain & $1.79 \mathrm{~b}$ & $-2.18 \mathrm{a}$ & $<0.01$ & $-2.44 b$ & $2.01 \mathrm{a}$ & $<0.01$ & 0.184 \\
\hline Longissimus thoracis area (LTA; $\left.\mathrm{cm}^{2}\right)$ & 9.93 & 9.73 & 0.677 & 9.89 & 10.12 & 0.330 & 0.130 \\
\hline Increase rate LTA $\left(\mathrm{cm}^{2} /\right.$ day $)$ & 0.07 & 0.07 & 0.126 & 0.07 & 0.08 & 0.716 & 0.003 \\
\hline Back fat thickness (BT) (mm) & 3.35 & 3.29 & 0.615 & 3.29 & 3.33 & 0.804 & 0.004 \\
\hline Increase rate BT (mm/day) & 0.03 & 0.02 & 0.223 & 0.03 & 0.03 & 0.464 & 0.0001 \\
\hline
\end{tabular}

SE - standard error

${ }^{1}$ Variable was transformed by Box Cox.

$\mathrm{a}, \mathrm{b}$ - Means followed by different letters in the row differ by $\mathrm{F}$ test at $5 \%$ probability. 
variables analyzed (Tables 2 and 3). Changes in LLA and $\mathrm{BT}$ and their growth rates were not confirmed by the results obtained in this study $(\mathrm{P}>0.05)$.

Total operational costs were higher in less efficient animals (higher RFI and lower RIG) (Table 4). Feeding was responsible for most part of TOC (71\%). A part of the FOC and the OC amounted to a high sum, superior to $\mathrm{R} \$ 43,000.00$ in all production systems, i.e., $23 \%$ of the total cost. The production systems had similar revenues. There was no correlation between RFI and RIG with final body weight (Table 4). Systems with efficient RFI and RIG lambs had higher gross margin values ( $\mathrm{R} \$ 51,165.87$ and $\mathrm{R} \$ 50,983.84)$ and net margin ( $\mathrm{R} \$ 34,501.05$ and $\mathrm{R} \$ 34,302.79)$, respectively.

When opportunity cost was included to obtain total cost, the systems composed of inefficient lambs (higher RFI and lower RIG) resulted in negative income (-R\$589.39 and $-\mathrm{R} \$ 338.79$, respectively) compared with efficient animals with lower RFI $(\mathrm{R} \$ 3,979.85)$ and higher RIG $(\mathrm{R} \$ 3,734.81)$.
All production systems were cost effective (return) and profitable (lucrative), but those with efficient animals had higher return values, 5.06 and 5.03\%, and profitability, 17.6 and $17.3 \%$, respectively, for lower RFI and higher RIG (Table 4).

Regarding the investment analysis, the results of cash flow by the IRR and NPV of all production systems were positive when including the appreciation of the land (Table 4). The NPV of R\$152,139.16 (lower RFI), $\mathrm{R} \$ 150,213.64$ (higher RIG), R $\$ 111,239.83$ (lower RIG), and $\mathrm{R} \$ 108,927.84$ (higher RFI), being the price of land included in the calculation, showed IRR of 8.05, 8.02, 7.49, and $7.46 \%$ per annum, respectively.

The result of the cash flow just off the sheep production activity, disregarding the appreciation of the land, indicated IRR of $6.70,6.64,5.50$, and $5.43 \%$ per annum for, respectively, lower RFI, higher RIG, lower RIG, and higher RFI (Table 4). With a value of opportunity rate below the $6 \%$ per annum, the NPV of $-\mathrm{R} \$ 19,331.98$ for higher RFI and $-\mathrm{R} \$ 17,019.98$ for lower RIG were obtained.

Table 4 - Cost analysis and investment analysis in lambs ranked high and low for residual feed intake and residual intake and BW gain

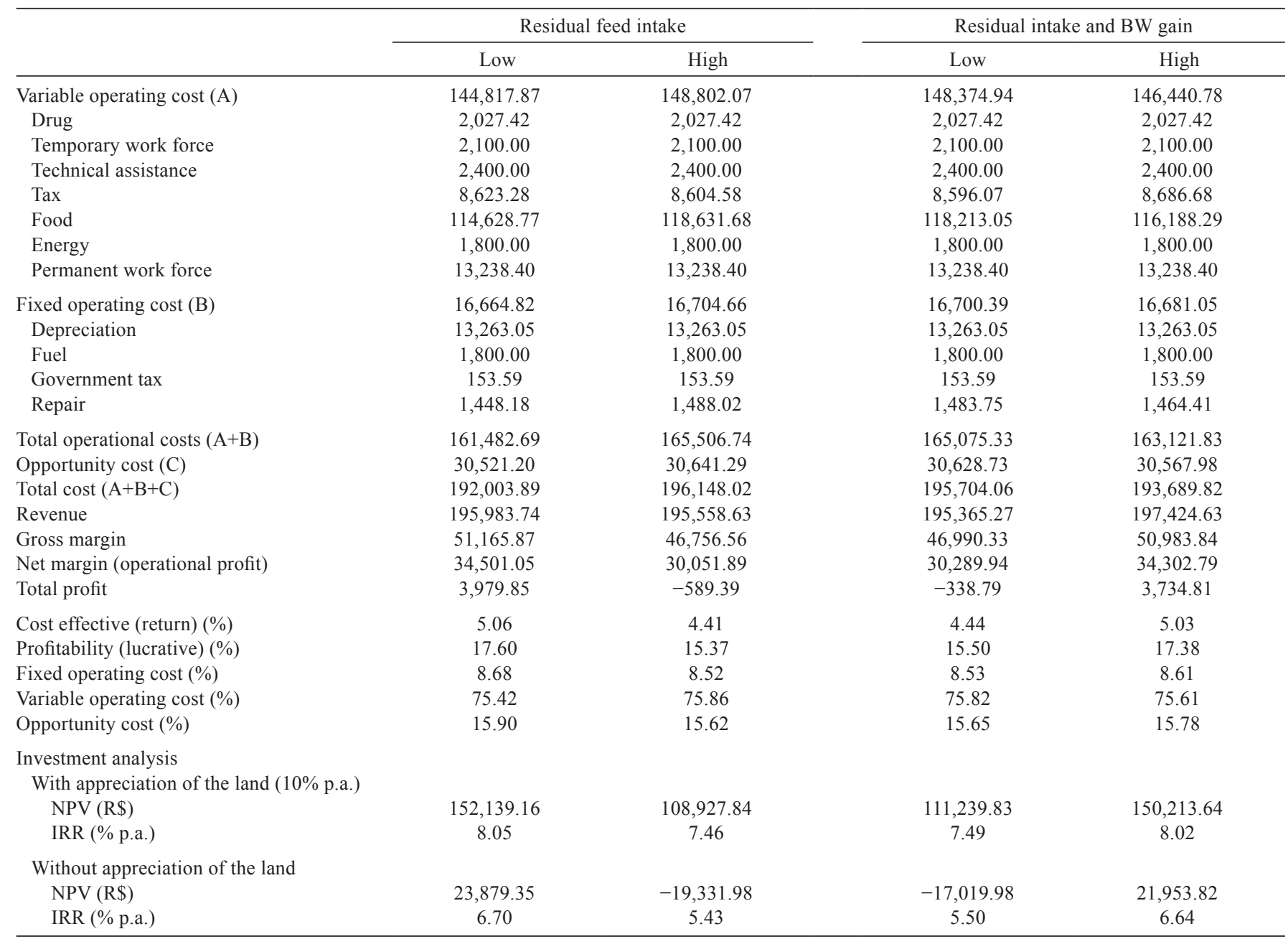

BW - body weight; NPV - net present value; IRR - internal rate of return. 


\section{Discussion}

The RFI had an average close to zero, which was expected, since this measure is the residue of a prediction equation. Animals with lower RFI consumed, on average, $0.17 \mathrm{~kg} /$ day feed, $12 \%$ less than the animals with higher RFI. A similar result was reported by Paula et al. (2013) evaluating Ile de France lambs regarding RFI, in which more effective animals consumed $0.21 \mathrm{~kg}$ /day of feed than those animals considered with superior RFI. Redden et al. (2011), Muro-Reyes et al. (2011), and Paula et al. (2013) found correlation coefficients between RFI and DMI in sheep of $0.77,0.58$, and 0.81 , respectively, values superior to the ones found in the present study.

As the definition of RFI considers ADG for the adjustment of regression, this leads to phenotypic independence between these characteristics (Sobrinho et al., 2011). As expected, several authors found no significant correlations between RFI and ADG, corroborating the results presented herein (Redden et al, 2011; Muro-Reyes et al., 2011 and Paula et al., 2013). Berry and Crowley (2012) reported differences in ADG of cattle of different classes for this measure, with the highest values found in animals with higher RIG (1.49 vs. $1.81 \mathrm{~kg} /$ day). Studies involving RIG in sheep are nonexistent; therefore, it was not possible to make a comparison with other published results. Feed efficiency measures and FC are simple ratios between DMI and ADG and provided that DMI did not differ in divergent animals to RIG, ADG was responsible for making efficiency measures (FE and FC) more favorable in these animals.

For relative growth rate and KR, similar to those found by Paula et al. (2013) in sheep, there were no differences between the classes of RFI of the lambs. Since the calculation of these rates considers body weight and ADG of the animals and do not correlate with RFI, the lack of significance for these measures is therefore justified. The correlations showed the importance of each trait of interest (BW, ADG, and DMI) in the composition of the indicator measures of feed efficiency. One of the major advantages of using RFI would be the reduced association with body weight and, consequently, with the maintenance of adult animals, especially mothers.

Paula et al. (2013), working with sheep, and Ramirez (2014), working with cattle, also reported no differences in carcass traits between animals of different RFI classes. Outcomes in the literature are contradictory on this fact as well as on the impact on the quality of meat of animals with lower RFI. Besides having a less tender meat, there is a possibility that animals identified as more efficient, take longer in terms of deposition of fat in the carcass. Changes in LLA and BT and their growth rates were not confirmed by the results obtained in this study, probably due to reduced age and maturity of the experimental animals (approximately five months), provided that puberty in sheep is manifested between six and nine months of age (Price et al., 1995). Studies showing the impact on the selection of more efficient animals concerning meat quality are needed, especially with lambs.

Works that show the economic feasibility and investment analysis in sheep production systems are scarce, being found in regional conditions, limited to a certain year and/or certain segment of production. Lacking such information, the use of simulation allows predicting an outcome designed according to each scenario (Martha Júnior et al., 2007). Therefore, to carry out the economic analysis of this production system, the DMI data and final body weight of the experiment from stage 1 aimed at verifying the economic impact of a herd with more or less efficient lambs regarding RFI and RIG.

Systems with efficient RFI and RIG lambs had higher gross margin values and net margin. Therefore, the highest profit margin in these systems was the DMI of lambs, as this measure was representative in total operational cost, which is part of the calculation of profit margins. When opportunity cost was included to obtain total cost, the systems composed of inefficient lambs (higher RFI and lower RIG) resulted in negative income. This means that the activity with inefficient lambs regarding RFI and RIG did not compensate the invested capital as in the best market alternatives. In these situations, there is no capacity for further medium- and long-term investments; thus, the activity is maintained, but may not be the most attractive investment option for the next generation (Barbosa and Souza, 2007).

All production systems were cost effective (return) and profitable (lucrative), but those with efficient animals had higher return values and profitability. Green (2008) cited the average of the percentage of return on investment over the previous 20 years in New Zealand, which is $10.5 \%$ in sheep properties, but Morris (2009) reported values of 1 to $2 \%$ per year, the worst in 50 years.

The investment analysis of all production systems was positive when including the appreciation of the land. It means that, at a discount rate of $6 \%$ per year, the sum of revenue within a 15-year period was higher than the investment in the activity. The net present value being the price of land included in the calculation showed IRR above the opportunity rate of $6 \%$ per annum, which was the same used for savings accounts. Therefore, the activities 
would be economically viable if the sale of the property was carried out at the end of the period, including land that showed an appreciation of $10 \%$ per annum.

The IRR must be the same or higher than the market interestrate(savings accounts and/or a comparison reference) and this positive result indicates that the capital invested in the activity is recovered and the balance available each year yields the same interest at IRR (Guimarães and Canziani, 2004). With the use of less efficient animals, the activity was not economically viable, even if sales of productive resources (pasture, herd, improvements, machinery, and equipment) were conducted at the end.

\section{Conclusions}

Considering residual feed intake and residual intake and body weight gain, efficient animals have satisfactory performance without alterations in the carcass traits measured by ultrasound.

The production system with the confinement of efficient lambs and according to residual feed intake and residual intake and body weight gain shows better results in both cost analysis and investment analysis.

\section{Acknowledgments}

We thank Fundação de Amparo à Pesquisa do Estado de Minas Gerais (FAPEMIG), Conselho Nacional de Desenvolvimento Científico e Tecnológico (CNPq), Institutional Program of Research Grants of Newly Engaged Doctors of PRPq/UFMG, Experimental Farm Prof. Hélio Barbosa of UFMG, and Izac Leopoldino Júnior (partner owner of OVINOZ ${ }^{\circledR}$ Ltda).

\section{References}

ANUALPEC - Anuário da Pecuária Brasileira. 2014. Informa Economics South America. 21.ed. FNP, São Paulo.

Archer, J. A.; Richardson, E. C.; Herd, R. M. and Arthur P. F. 1999. Potential for selection to improve efficiency of feed use in beef cattle: A review. Australian Journal of Agricultural Research 50:147-161.

Barbosa, F. A. and Souza, R. C. 2007. Administração de fazendas de bovinos: leite e corte. Aprenda Fácil, Viçosa, MG. 342p.

Barbosa, F. A.; Graça, D. S.; Andrade V. J.; Cezar, I. M.; Santos, G. G. and Souza, R. C. 2010. Produtividade e eficiência econômica de sistemas de produção de cria, recria e engorda de bovinos de corte na região sul do estado da Bahia. Arquivo Brasileiro de Medicina Veterinária e Zootecnia 62:677-685.

Barros, N. N. 2004. Acabamento de cordeiros em confinamento. Available at: <http://www.cnpc.embrapa.br/confinamento.htm>. Accessed on: Mar. 23, 2015.
Berry, D. P. and Crowley, J. J. 2012. Residual intake and body weight gain: A new measure of efficiency in growing cattle. Journal of Animal Science 90:109-115.

Brasil. 2014. Caixa Econômica Federal. Sistema Nacional de Pesquisa de Custos e Índices da Construção Civil - SINAPI. Available at: $<$ http://www.cef.com.br $>$. Accessed on: Jan. 12, 2014.

Canziani, J. R. F. 2005. O cálculo e a análise do custo de produção para fins de gerenciamento e tomada de decisão nas propriedades rurais. DERE/SCA/UFPR, Curitiba.

CONAB - Companhia Nacional de Abastecimento. 2010. Metodologia de cálculo de custo de produção da CONAB. Available at: $<$ http:// www.conab.gov.br/conabweb/download/safra/custosproducaomet odologia.pdf $>$. Accessed on: Mar. 20, 2015.

Della Giustina, J. S. and Lanzer, E. A. 1995. Um sistema de contabilidade analítica para apoio a decisões do produtor rural. Universidade Federal de Santa Catarina, Centro Tecnológico, Florianópolis. 90p.

Detmann, E.; Cecon, P. R.; Andreotti, M. O.; Resende, F. D.; Sousa, D. P.; Ponciano, N. J.; Campos, J. M. S.; Souza, P. M. and Vittori, A. 2005. Avaliação da primeira variável canônica na avaliação de experimentos de desempenho produtivo com animais. Revista Brasileira de Zootecnia 34(Supl. 1):2417-2426.

Detmann, E.; Souza, M. A.; Valadares Filho, S. C.; Queiroz, A. C.; Berchielli, T. T.; Saliba, E. O. S.; Cabral, L. S.; Pina, D. S.; Ladeira, M. M. and Azevedo, J. A. G. 2012. Métodos para análise de alimentos. Instituto Nacional de Ciência e Tecnologia de Ciência Animal. Suprema, Visconde do Rio Branco.

FAEMG - Federação da Agricultura e Pecuária do Estado de Minas Gerais. 2012. Índice de preços de terras. FAEMG, Belo Horizonte. Available at: $<$ http://www.faemg.org.br/Conteudo.aspx?Code $=69 \&$ Portal $=2 \&$ ParentCode $=67 \&$ ParentPath $=$ None $\&$ ContentVersion $=\mathrm{R}>$. Accessed on: Apr. 10, 2015.

FAEP - Federação da Agricultura do Estado do Paraná. 2005. Sistema de acompanhamento do custo de produção do leite no Paraná. 1.ed. FAEP, Curitiba.

Fitzhugh, H. A.; Taylor, C. S. St. 1971. Genetic analysis of degree of maturity. Journal of Animal Science 33:717-725.

Green, R. B. 2008. Innovative and adaptive future farming particularly as it relates to profitable use of dry land country in New Zealand a personal view. In: Proceedings of the New Zealand Grassland Association 70:7-11.

Grion, A. L.; Mercadante, M. E. Z.; Cyrillo, J. N. S. G.; Bonilha, S. F. M.; Magnani, E. and Branco, R. H. 2014. Selection for feed efficiency traits and correlated genetic responses in feed intake and weight gain of Nellore cattle. Journal of Animal Science 92:955-965.

Guimarães, V. Di. A. and Canziani, J. R. 2004. Análise econômica, financeira e de decisão. DERE/SCA/UFPR, Curitiba.

Kleiber, M. 1947. Body size and metabolic rate. Physiological Reviews 27:511-541.

Koch, R. M.; Swiger, L. A.; Chambers, D. and Gregory, K. E. 1963. Efficiency of feed use in beef cattle. Journal of Animal Science 22:486-494.

Leme, P. R. and Gomes, R. C. 2007. Características de carcaça de novilhos Nelore com diferente consumo alimentar residual. In: Anais XX Reunión Asociasón Latinoamericana de Producion Animal (ALPA). Cuzco, Perú.

Lima, N. L. L.; Silva Sobrinho, A. G.; Almeida, F. A.; Endo, V.; Zeola, N. M. B. L.; Almeida, A. K. and Sampaio, A. A. M. 2013. Quantitative and qualitative characteristics of the non-carcass componentes and the meat of lambs fed sunflower seeds and vitamin E. Revista Brasileira de Zootecnia 42:51-60.

MAPA - Ministério da Agricultura, Pecuária e Abastecimento. 2008. Lavoura e pastagem valorizam terras brasileiras. Available at: 
$<$ http://www.agricultura.gov.br/comuni-cacao/noticias/2008/03/ lavoura-e-pastagem-valorizam-terras-brasileiras $>$. Accessed on: Apr. 3, 2015.

Martha Júnior, G. B.; Vilela, L. and Maciel, G. A. 2007. A prática da integração lavoura pecuária como ferramenta de sustentabilidade econômica na exploração pecuária. p.367-391. In: Anais Simpósio de Forragicultura e Pastagens. UFLA, Lavras.

Morris, S. T. 2009. Economics of sheep production. Small Ruminant Research 86:59-62.

Muro-Reyes, A.; Gutierrez-Banuelos, H.; Diaz-Garcia, L. H.; Gutierrez-Pina, F. J.; Escareno-Sanchez, L. M.; BanuelosValenzuela, R.; Medina-Flores, C. A. and Corral Luna, A. 2011. Potential environmental benefits of residual feed intake as strategy to mitigate methane emissions in sheep. Journal of Animal and Veterinary Advances 10:1551-1556.

Nascimento, M. L. 2011. Eficiência alimentar e suas associações com lucro, características de carcaça e qualidade de carne de bovinos Nelore. Tese (D.Sc.). Escola Superior de Agricultura Luiz de Queiroz, Universidade de São Paulo, Piracicaba.

NRC - National Research Council. 2007. Nutrient requirements of small ruminants. National Academy Press, Washington.

Oliveira, P. P. A.; Trivelin, P. C. O. and Oliveira, W. S. 2003. Eficiência da fertilização nitrogenada com ureia $(15 \mathrm{~N})$ em Brachiaria brizantha $\mathrm{cv}$. Marandu associada ao parcelamento de superfosfato simples e cloreto de potássio. Revista Brasileira de Ciência do Solo 27:613-620.

Paula, E. F. E.; Monteiro, A. L. G.; Souza, D. F.; Prado, O. R.; Nomura, T. M.; Stivari, T. S. S.; Silva, C. J. A. and Santana, M. H. A. 2013. Consumo alimentar residual e sua relação com medidas de desempenho e eficiência e características in vivo da carcaça de cordeiros. Arquivo Brasileiro de Medicina Veterinária e Zootecnia, 65:566-572.
Pitelli, M. M. and Bacha, C. J. C. 2006. Análise dos principais tributos incidentes na cadeia de carne bovina brasileira. In: Anais do $44^{\circ}$ Congresso Brasileiro de Economia, Administração e Sociologia Rural, Fortaleza. SOBER, Brasília.

Price, E. O.; Borgwardt, R. and Dally, M. R. 1995. Heterosexual experience differentially affects the expression of sexual behavior in 6- and 8-month-old ram lambs. Applied Animal Behaviour Science 46:193-199.

Ramirez, J. A. 2014. Effects of residual feed intake classification on temperament, carcass composition, and feeding behavior traits in growing Santa Gertrudis heifers. Thesis (M.Sc.). Universidade do Texas A\&M. Available at: <http://oaktrust.library.tamu.edu/ handle/1969.1/152623? show=full>. Accessed on: Mar. 5, 2015.

Redden, R. R.; Surber, L. M. M.; Roeder, B. L.; Nichols, B. M.; Paterson, J. A. and Kott, R. W. 2011. Residual feed efficiency established in a post-weaning growth test may not result in more efficient ewes on the range. Small Ruminant Research 96:155-159.

Santana, R. A. V.; Barbosa, F. A.; Mandarino, R. A.; Lobo, C. F. 2013. Desempenho bioeconômico de sistemas intensivos de cria e de ciclo completo por meio de simulação. Arquivo Brasileiro de Medicina Veterinária e Zootecnia 65:1773-1782.

Santana, M. H. A.; Gomes, R. C.; Ferraz, J. B. S. and Rossi Júnior, P. 2014. Medidas de eficiência alimentar para avaliação de bovinos de corte. Scientia Agraria Paranaensis 13:95-107.

Sobrinho, T. L.; Branco, R. H.; Bonilha, S. F. M.; Castilhos, A. M.; Figueiredo, L. A.; Razook, A. G. and Mercadante, M. E. Z. 2011. Residual feed intake and relationships with performance of Nellore cattle selected for post weaning weight. Revista Brasileira de Zootecnia 40:929-937. 